\title{
ASSESSMENT OF FACTORS OF SUSTAINABLE DEVELOPMENT OF THE AGRICULTURAL SECTOR USING THE COBB-DOUGLAS PRODUCTION FUNCTION
}

\author{
Olena Vasyl'yeva ${ }^{1}$
}

\begin{abstract}
The aim of the article is to assess the impact of various factors (forms of capital) on the formation of gross value added and gross output of the agricultural sector of Ukraine's economy under sustainable development using the modified Cobb-Douglas production function. Methods. The theoretical and methodological basis of the study consisted of the papers on economic growth, sustainable development and forecasting by scientists in classical and modern economics. A monographic method was used to cover the scientists' views on the research issue. The parameters of the production function describing how variables (physical and human capital, pollutant emissions) act on gross value added and gross output of the agricultural sector of Ukraine were estimated on the basis of the modified Cobb-Douglas production function. Statistics for agriculture covering the period 2008-2018 were used for the assessment. The correlation and regression analysis was used to determine and verify the parameters of the production function. Equations of balance and construction of isoquants were used to foresight the optimal combinations of factors of the production function. Results. Using the Cobb-Douglas production function, econometric analysis with eco-socio-economic factors has shown that economic growth in agriculture is associated with improved quantitative and qualitative characteristics of labour potential, growing capital investment and reducing pollutant emissions. Estimation of the elasticity coefficients of the constructed Cobb-Douglas function (the sum exceeds 1) justifies that the economic development of agriculture mainly contains the features of a largescale economy: modern level of science and technology provides advantageous expanding production to increase output. Practical significance. The constructed models allow to forecast assessment of the development of the agricultural sector's components and can be used to develop the basic directions of the state agricultural policy to manage the formation and use of resource potential. Value/originality. Modelling how the resource factors act on output using the method of construction and calculation of parameters of the production function allows to predict the sustainable development of agricultural production under quantitative and qualitative changes in the use of labour and capital, as well as environmental factors. Further research ensures obtaining a dynamic multi-factor model of sustainable development of the agricultural sector and determining the main mechanisms of influence on the levers of economic growth.
\end{abstract}

Key words: sustainable development, agriculture, economic growth, labour potential, Cobb-Douglas function, elasticity coefficients, isoquants.

JEL Classification: C23, E13, O11, O13

\section{Introduction}

The conceptual change of understanding the priorities of social and economic goals of development, the search for ways to move to the principles of sustainability are urgent for global development. According to modern scientists, it is possible to achieve sustainable development in three scenarios (Hopwood, 2005): 1) reducing the government regulation, increasing the role of informatization and implementation of new technologies will help achieve sustainable development

\footnotetext{
Corresponding author:

${ }^{1}$ National University «Zaporizhzhia Polytechnic», Ukraine.

E-mail: olena.vasilyeva@gmail.com

ORCID: https://orcid.org/0000-0003-2859-3592
}

goals without significant changes in government relations (liberal approach); 2) increasing the role of government regulation, technology and science through public administration reform (reformist approach); 3) transforming society's interaction with the environment through radical changes (transformist approach). The sustainable development mechanism for the agricultural sector should be considered through the interconnected structural components: economic, environmental, social, institutional and legal. 
Sustainable development of the agricultural sector not only guarantees food security as one of the components of general economic security of the state but also provides economic growth, rural development, stimulates the progress of other industries through a multiplier effect. The agricultural sector of Ukraine demonstrates positive dynamics due to the significant natural and human potential, as well as favourable climatic conditions. The objective construct "agricultural sector" is a system of agricultural production, environment and rural population; therefore, the agricultural sector is as close as possible to environmental and food challenges. The agricultural sector combines social, production, and environmental functions, sectoral and territorial aspects: the basic agricultural sector which generates the rural environment with the appropriate resource base (spatial, natural, and labour).

Ukrainian agricultural products occupy a significant share in the gross value added, which gives grounds for arguing about the prospects of increasing the volume of exported agricultural products under the optimal combination of production factors (Vasylieva, 2017). The transition to sustainable development principles, a new paradigm of social development, mainstreams the issue of effective interaction of production factors in the process of making a product in the economy. Sustainable economic growth is based on the involvement of endogenous factors that depend on human economic activity; their interaction within the endogenous theory can be described using the apparatus of the production function.

The article is aimed at assessing the impact of various factors (forms of capital) on the formation of gross value added and gross output of the agricultural sector of Ukraine's economy under sustainable development using the modified Cobb-Douglas production function.

\section{Theoretical framework and related studies}

Scholars consider sustainable development from the standpoint of preserving and increasing all types of capital for future generations (human, natural, and material) (Khvesyk, 2012).

The three-pronged concept of sustainable development originated from the provisions in the Proclamation of Teheran, Final Act of the International Conference on Human Rights in 1968; here, economic and social development was declared as imperatives for sustainable progress, as "ensuring human rights to life, consistent with freedom and dignity, contributing to physical, social and spiritual well-being" (Proclamation of Teheran, 1968). For the first time, development was additionally considered a means to ensure human rights and freedoms, including peaceful and secure existence.

Originating of the modern concept of sustainable development is associated with the Declaration of the UN Conference on the Human Environment (Stockholm, 1972), which emphasizes the relationship of economic and social development with environmental issues, and the famous report to the Club of Rome "The Limits to Growth" (1972) prepared by Dennis Meadows, which addresses the impact of global environmental constraints on resource use and emissions in the 21st century on global development. D. Meadows' study concludes that humanity needs to make a "controlled orderly transition from growth to global equilibrium" (Meadows, 1991). "The Limits to Growth" formulates the ideas of the transition of civilization from quantitative growth to "organic" (qualitative) and "new world economic order" with deep, proactive social innovation through technological, cultural and institutional changes to avoid the growth of negative environmental impact without respecting the Earth's ecological limits (Meadows, 2018).

Accelerated degradation of the natural environment as a result of human activities poses a global threat to humanity. In 1987, the UN World Commission on Environment and Development, in a report by the Chairman of the World Commission on Environment and Development, Prime Minister of Norway Gro Harlem Brundtland "Our Common Future", justified the need to find a new model of civilization development. The model indicated that the needs of modern generations should not jeopardize the interests of future generations in the realization of their needs and opportunities. According to G. H. Brundtland, the history of humankind reached a level at which a change in political priorities was inevitable: savings from arms reduction can be used to finance environmental security measures. G. H. Brundtland introduced the term "sustainable development", which implied a "model of development, where the satisfaction of the vital needs of the present generation was achieved without depriving future generations of such an opportunity" (Koptug, 1997). The Brundtland Commission defined the concept of sustainable development under globalization, technological and social factors from the standpoint of overcoming poverty through respecting ecological limits to meet the needs of present and future generations. Consequently, G. H. Brundtland's anthropocentric approach to sustainable development, in which the environment was a means of human existence, comprised a relationship of needs and constraints (Slavgorodska, 2016).

The participants of the UN Conference on Sustainable Development "Rio+20" (2012) in the Rio de Janeiro Earth Summit recognize that fair and sustainable use of resources is the key factor in choosing a path to a safer, cleaner and more prosperous world for all (United Nations Conference on Sustainable Development, 2012). The Resolution “The Future We Want” adopted by the General Assembly (Resolution adopted by the General Assembly, 2012) emphasizes the following 
aspects: the recognition of the need to further promote the idea of sustainable development at all levels; integration of its economic, social and environmental components; taking into account the relationship of the latter in order to achieve the goals of sustainable development in all the aspects.

Consequently, sustainable development should not focus exclusively on environmental aspects; it is considered in terms of harmonization of resource use, innovation and investment processes, institutional change with the needs of present and future generations.

The positive dynamics of the economic potential of the agricultural sector as a set of all available means, opportunities, productive forces, resources, stocks, competencies that can be used in production and realize market opportunities to achieve socio-economic development is a necessary condition for sustainable development (Vasylieva, 2019).

The production potential of agricultural production can be determined in terms of a hybrid approach, which includes resource (as a set of production resources) and effective (as the creation of a certain amount of material goods) approaches: the ability to produce a certain amount of material goods through the use of limited interconnected resources (Suvorov, 2020).

For forecasting in macroeconomics, the apparatus of production functions describing complex production processes is used. The production function is a complex model of economic dynamics that characterizes the economic and mathematical dependence of output (quantity of products) on the factors of production used (resources, technology). The classical equation of the production function for agricultural production includes factors of economic growth: production assets $\mathrm{K}$ (area of agricultural land, the number of fixed and production assets in value form), total living labour costs $L$ (number of employees in agriculture, working time) and other factors that take into account technical progress $\mathrm{N}$ :

$$
Y=f(K, L, N)
$$

In the macroeconomic analysis, CES-function (Yankovyi, 2015) with constant elasticity of substitution of resources is used for economic and mathematical modelling:

$$
Y=A\left[\alpha K^{-\rho}+(1-\alpha) L^{-\rho}\right]^{-\gamma / \rho},
$$

where $Y$ is the production in monetary terms, $K$ is a cost of capital, $L$ is labour costs, $A$ is a scale factor, $\alpha$ is a weighting coefficient of the production factor, $\gamma$ is an indicator of the degree of uniformity, $\rho$ is a production function parameter.

At $\rho=-1$, CES-function has the form of a linear equation (elasticity of substitution is unlimited):

$$
Y=a_{1} K+a_{2} L,
$$

where $a_{1}, a_{2}$ are parameters that characterize the qualitative impact of each factor.
At $\rho \rightarrow 0$, CES-function becomes the CobbDouglas production function (elasticity of substitution tends to 1$)$ :

$$
Y=a_{0} K^{a_{1}} L^{a_{2}}
$$

where $a_{0}$ is a parameter that characterizes the level of technology, $a_{1}$ and $a_{2}$ are coefficients that characterize the contribution of capital and labour to output growth. $a_{1}, a_{2}$ parameters of the estimation model characterizes the production elasticity by resources, i.e., the quantitative relationship between production volumes in accordance with resources in relative (percentage) terms.

At $\rho \rightarrow \infty$, CES-function becomes the Leontief production function with constant proportions of production factors (zero elasticity of substitution):

$$
Y=A \min \left(\frac{K}{K_{0}} ; \frac{L}{L_{0}}\right)
$$

For the classical Solow growth model that considers the influence of key production factors on output dynamics, Solow (1961), Barro (2010), and Lyashenko (2013) propose to use the Cobb-Douglas production function with the possibility and limitation of substitution, which is the most adequate model in terms of identifying potential sources of growth. The twoinput Cobb-Douglas production function is considered classic; here capital and labour are considered resources (Cobb, 1928). Further research leads to the creation of a modified production function that takes into account the exogenous neutral factor (Solow, 1957; Arrow, 1961), entrepreneurial skills and innovation (Schumpeter, 1934), human capital (Romer, 1986; Lukas, 1988), intellectual and social capital (Kramin, 2016). In the model of economic growth, the American economists Mankiw, Romer and Weil (1992) focuse on the quality of the workforce and introduce a factor of intellectual capital which includes the cost of education and science. Romer (1996) believes that the emergence of new ideas and technologies (intangible resources) leads to the creation of more valuable material resources. Oliner and Sichel (2000) consider information technology an important factor in economic growth and technological progress. Solow (Solow, 1956, 1957) proposes to take into account technological progress, which is the main reason for productivity growth and development of the US economy in the first half of the 20th century by changing the quality characteristics of labour potential and improving labour organization (training, improving production etc.). In this case, the endogenous production function may include three main factors: labour $(L)$, physical capital $(K)$ and skill level $(H)$ (Moreno-Hurtado, 2018, p. 172).

In the economic literature there is a general consensus on innovations that play an important role in increasing the competitiveness of firms, industries, regions, and countries (Asheim et al., 2011, p. 1133-1139; Tödtling 
\& Grillitsch, 2015, p. 1741-1758; Zygmunt, 2019, p. 292), and contribute to sustainable development (Klewitz \& Hansen, 2014; Zygmunt, 2020). It is the availability of intellectual assets as important indicators of innovation efficiency that is crucial for economic growth (Zygmunt, 2019). Novakova (2020, p. 11) also concludes on the importance of increasing investment in human development, improving cognitive skills as a prerequisite for sustainable economic development. Marynych (2017) confirms the positive effect of education as a factor of human capital and the untapped potential of the technological factor in ensuring sustainable development of the region. To determine the growth model of the Russian economy Glinskiy et al. (2018) uses the modified Cobb-Douglas production function that includes an innovation factor. For forecasting the economicgrowth of Ukraine's agricultural sector, Odintsov et al. (2020, p. 153) propose to expand the typical Cobb-Douglas production function due to the "exponential factor of land resources, the cost of innovation and the parameters of state regulation of the tax system (the function includes salary, capital investments, land resources, financing of innovation activities in the agricultural sector of the economy and the tax burden on the industry)".

Sustainable development involves the relationship between economic benefits and environmental impacts. Lyashenko (2012, p. 187) proposes to use the ecological and economic balance taking into account the efficient use of resources and minimization of pollutant emissions. The agricultural sector produces $90 \%$ of nitric acid emissions, $70 \%$ of methane and $20 \%$ of carbon dioxide emissions worldwide (Çetin, 2020). In this case, we believe that to study the factors of sustainable development it is advisable to use environmental and economic production function, including an indicator of environmental pollution as an exogenous factor that negatively affects the results of agricultural production. Yang et al. (2020, p. 166) use both the quantitative and qualitative parameters of labour and environmental impact in the Cobb-Douglas production function to study the sustainable development of China's economy. The authors believe that the main drivers of China's economic growth are physical and human capital, as well as the minimization of environmental pollution to achieve sustainable development. In "The core function of sustainable development" (2015), Tkach proposes a basic function of sustainable development under the information economy, a partial case of which is the modified Cobb-Douglas function, which includes different types of capital: physical, natural, human and information. Dedrick (2003) and Gosinska (2020) use gross value added, which is the main indicator for assessing the performance of the industry and the economy as a whole, as a performance indicator.

\section{Methods}

To obtain maximum profit in terms of sustainable development we should apply the methodology of construction of the production function, which allows to determine the optimal combination of resources taking into account economic, social and environmental factors. Based on previous studies, we propose to use the four-input Cobb-Douglas production function in terms of sustainable development of agriculture to take into account not only the quantitative parameters of labour potential but also its qualitative indicators (integral coefficient of intellectual assets), as well as environmental impact:

$$
Y=a_{0} K^{a_{1}} L^{a_{2}} I^{a_{3}} E^{a_{4}}
$$

where $Y$ is the performance indicator (output), $K$ is a fixed capital or fixed assets used (capital investment), $L$ is the living labour costs (number of employees in agriculture), $I$ is an integral coefficient of intellectual assets, $E$ is the pollutant emissions, $a_{0}$ is a technological coefficient that characterizes the efficiency of production, takes into account the complex influence of qualitative determinants of labour potential, the influence of factors that cannot be quantified (a technical progress indicator); $a_{i}$ are the coefficients of elasticity that characterize the contribution of capital, labour, intellectual assets and pollutant emissions to growth of the output $Y$ (i.e., $a_{i}$ are fractions of factors).

The sum of the elasticity coefficients $a_{1}+a_{2}+\ldots+a_{n}$ characterizes the economies of scale (Kuzmin, 2020, p. 787):

- increasing returns to scale if $a_{1}+a_{2}+\ldots+a_{n}>1$ (intensive economic growth), the function grows disproportionately, product growth outpaces the growth of factor costs;

- constant returns when changing the scale of production if $a_{1}+a_{2}+\ldots+a_{n}=1$ (extensive economic growth), the Cobb-Douglas production function is linearly homogeneous, the level of resource efficiency does not depend on the scale of production;

- returns to scale decrease if $a_{1}+a_{2}+\ldots+a_{n}<1$ (lack of economic growth), the function decreases disproportionately, the increase in the factor costs is accompanied by a slowdown in output growth.

Kuzina (2018, p. 73) defines the main characteristics of the Cobb-Douglas production function: it is increasing, has no extremes, the rate of output slows down with increasing resources, output increases indefinitely with unlimited growth of one of the resources.

The advantages of the Cobb-Douglas production function include the following aspects:

- the form of the Cobb-Douglas production function is relatively simple to use, which allows you to easily determine the indicators of productivity and return 
on assets, the output elasticity for all parameters, the marginal rates of substitution;

- the Cobb-Douglas production function is able to describe the state of returns to scale, regardless of they increase, are stable or decrease;

- practical universality and adequacy: the CobbDouglas production function coefficients directly describe the elasticity of each input factor used;

- macroeconomic orientation: it is based on real economic indicators of official statistical reporting and can be easily parameterized using correlation and regression analysis;

- realism: the functional dependence of the result on costs is nonlinear and does not contain the shortcomings characteristic of linear production functions that describe the processes of an ideal economy.

Despite these advantages, the production function also has a number of disadvantages:

- the production function with the constant economies of scale may inadequately reflect the production process (in conditions of intensive growth of factors, the economies of scale are greater than 1);

- this is based on the assumption of full interchangeability of production resources;

- determining the parameters of the production function is based on marginal prices of factors equal to average prices and calculated on the basis of market prices; this is possible in conditions of perfect competition and market, not in the real economy;

- the principle of complementarity that takes into account the capital structure is ignored.

\section{Results and discussion}

\subsection{The construction of the Cobb-Douglas production function for agricultural production in Ukraine}

For conducting an empirical study of the agricultural sector of the economy and the construction of the production function, the relationship between the basic production resources (labour, capital, intellectual assets and emissions of pollutants) and output was used. In a market economy, the main indicator of the degree of development of the industry is gross value added, which reflects the possibility of expanding production. In this case, gross value added and gross output of agriculture are considered performance indicators.

The model considered in the work uses the data of the annual reports of the State Statistics Service of Ukraine (2020): gross value added, gross output of agriculture $Y(T)$, the amount of fixed capital $K(T)$, the number of employees in agriculture $L(T)$ and pollutant emissions $E(T)$; indicators of the integral coefficient of intellectual assets $I(T)$ given in the paper by Karpenko (2018). The statistics shown in Table 1 were used to calculate the Cobb-Douglas production function with the performance indicator "gross value added".

Correlation and regression analysis is used to determine and verify the parameters of the production function. The approximation of wellknown power functions in the Cobb-Douglas production function helps mitigate mistakes and close in on real values.

For the calculation, the logarithm of both parts of the equation of the production function is taken:

$$
\ln Y=\ln a_{0}+a_{1} * \ln K+a_{2} * \ln L+a_{3} * \ln I+a_{4} * \ln E .
$$

After appropriate replacements, a linear function is obtained:

$$
\begin{aligned}
& Y_{1}=a_{0}+a_{1} * X_{1}+a_{2} * X_{2}+a_{3} * X_{3}+a_{4} * X_{4}, \\
& \text { where } a_{0}=\ln a_{0} .
\end{aligned}
$$

After calculations using linear regression analysis by the method of least squares, the values of the coefficients of the Cobb-Douglas production function are determined. The production function obtained takes the form:

$$
Y=422388 K^{0,34474} L^{2,63344} I^{1,60806} E^{-2,86638}
$$

Table 1

Statistics for calculations of the production function $(Y(T)$ is the gross value added)

\begin{tabular}{|c|c|c|c|c|c|c|c|c|c|c|}
\hline$T$, year & $\begin{array}{c}Y(T), \\
\text { mln UAH }\end{array}$ & $\begin{array}{c}K(T), \\
\text { mln UAH }\end{array}$ & $\begin{array}{c}L(T) \text {, thous } \\
\text { persons }\end{array}$ & $I(T)$ & $\begin{array}{c}E(T), \\
\text { thous t }\end{array}$ & $y_{1}=\ln Y$ & $x_{1}=\ln K$ & $x_{2}=\ln L$ & $x_{3}=\ln I$ & $x_{4}=\ln E$ \\
\hline 2008 & 65148 & 16682 & 3322.1 & 0.5 & 7210.3 & 11.1 & 9.7 & 8.1 & -0.6 & 8.9 \\
\hline 2009 & 65758 & 9295 & 3152.2 & 0.5 & 6442.9 & 11.1 & 9.1 & 8.1 & -0.7 & 8.8 \\
\hline 2010 & 82948 & 11311 & 3115.6 & 0.6 & 6678.0 & 11.3 & 9.3 & 8.0 & -0.4 & 8.8 \\
\hline 2011 & 109961 & 17981 & 3410.3 & 0.6 & 6877.3 & 11.6 & 9.8 & 8.1 & -0.6 & 8.8 \\
\hline 2012 & 113245 & 18564 & 3506.7 & 0.6 & 6821.1 & 11.6 & 9.8 & 8.2 & -0.5 & 8.8 \\
\hline 2013 & 132354 & 18175 & 3389 & 0.6 & 6719.8 & 11.8 & 9.8 & 8.1 & -0.5 & 8.8 \\
\hline 2014 & 161145 & 18388 & 3091.4 & 0.6 & 5346.2 & 12.0 & 9.8 & 8.0 & -0.5 & 8.6 \\
\hline 2015 & 239806 & 29310 & 2870.6 & 0.5 & 4521.3 & 12.4 & 10.3 & 8.0 & -0.7 & 8.4 \\
\hline 2016 & 279701 & 49660 & 2866.5 & 0.5 & 4498.1 & 12.5 & 10.8 & 8.0 & -0.7 & 8.4 \\
\hline 2017 & 303949 & 63401 & 2860.7 & 0.5 & 3879.1 & 12.6 & 11.1 & 8.0 & -0.8 & 8.3 \\
\hline 2018 & 360757 & 65059 & 2937.6 & 0.4 & 3866.7 & 12.8 & 11.1 & 8.0 & -0.8 & 8.3 \\
\hline
\end{tabular}


To assess the calculated production function (7), the parameters of regression analysis are studied. The multiple correlation coefficient is $\mathrm{R}=0.983$, the standard approximation error is 0.148. Fisher's F-criterion calculated is 46.71 and is greater than Fisher's F-criterion tabular (99\% confidence, reliability), which is 8.45 (Table 2). Therefore, the regression equation obtained can be considered significant. This means that with a $99 \%$ probability the found Cobb-Douglas production function (3) corresponds to the initial data of the problem.

Table 2

Regression analysis parameters

for $\boldsymbol{Y}(\boldsymbol{T})$ (gross value added)

\begin{tabular}{|l|c|}
\hline Multiple correlation coefficient $R$ & 0.983 \\
\hline Coefficient of determination $R^{2}$ & 0.966 \\
\hline Standard approximation error & 0.148 \\
\hline Fisher's F-criterion calculated $F_{\text {calc }}$ & 46.71 \\
\hline Fisher's F-criterion tabular $F_{\text {tab }}$ & 8.45 \\
\hline Number of observations & 11 \\
\hline
\end{tabular}

Thus, the constructed production function has reliable statistical characteristics. The value of the multiple correlation coefficient indicates a high close relationship between the performance indicator and the selected factors, the variation of gross value added by $98.3 \%$ depends on the fluctuations of the factors included in the equation and only $1.7 \%$ depends on factors that are not taken into account. The value of the coefficient of determination $R^{2}(0.966)$ is quite close to 1 , so the regression model is successful, and the relationship between the resulting indicator of the production function and the input factors is strong. Variance of the output $Y(T)$ is due to the regression of the selected levers of influence (K, L, I, E) by $96.6 \%$. This confirms that the model takes into account the most important factors. In addition to the multiple correlation coefficient, the adequacy of the equation is evidenced by the small value of the average approximation error, which characterizes the average relative deviation between the actual and theoretical values based on the equation constructed (Figure 1). Thus, equation (7) meets all the requirements and can be used for economic analysis.

The analysis shows that the growth of quantitative and qualitative indicators of labour potential of the agricultural sector has a direct impact on the growth of gross value added of agricultural products, as there is a direct relationship between them.

The economic analysis of the Cobb-Douglas production function can be performed on the basis of elasticity coefficients that reflect the nature of the influence of factors on performance. For example, the elasticity coefficient $a_{1}=0.34474$ (7) shows the elasticity of agricultural production relative to capital investment with a constant number of employed persons in rural

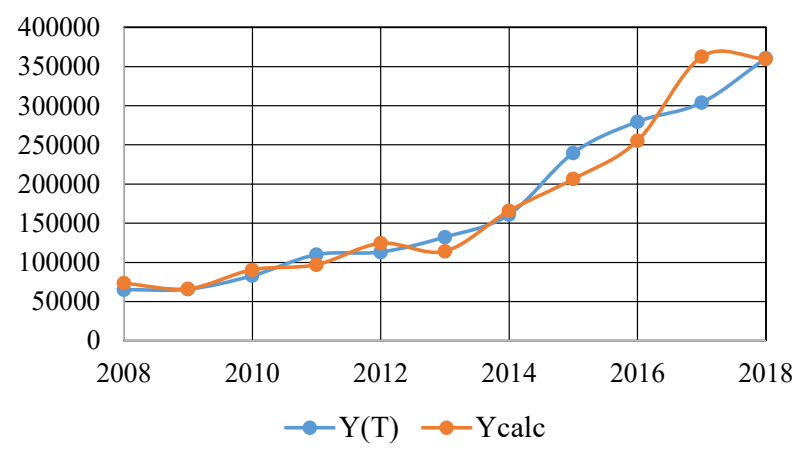

Figure 1. Results of the approximation of the Cobb-Douglas production function for gross value added

areas, the integral coefficient of intellectual assets and pollutant emissions. If capital investment increases by $1 \%$, the gross value added of agriculture should be expected to grow by $0.34474 \%$. The elasticity coefficient $a_{2}=2.63344$ (7) indicates the output elasticity relative to the number of employed persons in rural areas with constant capital investment, the integral coefficient of intellectual assets and pollutant emissions, i.e., with an increase in the number of employed persons in rural areas in agriculture by $1 \%$ gross value added of agriculture should increase by $2.63344 \%$. The elasticity coefficient $a_{3}=1.60806$ (7) reflects the elasticity of production relative to the integral coefficient of intellectual assets with a constant amount of capital investment, the number of employed persons in rural areas and the number of pollutant emissions, i.e., if the integral coefficient of intellectual assets increases by $1 \%$, an increase in gross value added by $1.60806 \%$ should be expected. The elasticity coefficient $a_{4}=-2.86638$ (7) shows the elasticity of production relative to pollutant emissions with constant capital investment, employed persons in rural areas and the integral coefficient of intellectual assets, i.e., with an increase in pollutant emissions by $1 \%$, reduction of agricultural output by $2.86638 \%$ should be expected. The value of the technological coefficient $a_{0}$ obtained (422388) is much more than 1 . We can justify a significant impact of technical progress on the growth of gross value added in agriculture.

This means that the increase in gross value added is, firstly, due to an increase in the number of employees $\left(a_{2}>a_{1}\right)$; secondly, this is possible due to improving the quality characteristics of labour potential $\left(a_{3}>a_{1}\right)$. This type of economic growth cannot be called labour-saving; according to Solow, the transition to a model of the production function with scientific and technological progress requires qualitative changes in production processes, improving the efficiency of labour resources and productivity.

Thus, the most significant in the economic growth of agricultural production are quantitative and qualitative indicators of labour potential: the number of employed persons $(L)$ and the integral coefficient of intellectual 
assets $(I)$, while the capital factor is less influential. This reveals the need to update the issue of priority of development of labour potential of the agricultural sector.

Aggregate influence of factors $\left(a_{1}+a_{2}+a_{3}+a_{4}\right)$ exceeds 1: $\left(a_{1}+a_{2}+a_{3}+a_{4}\right)=1,72>1$. This indicates the positive strength of their influence; the resulting production function describes the growing economy (Pshenychnykova, 2017) within the endogenous model of growth. The economic development of agriculture mainly has the characteristics of a large-scale economy: at the current level of science and technology, it is advantageous to expand production for increasing output.

Similarly, there is conducted a study of the CobbDouglas production function, which considers the gross output of agriculture Ukraine a performance indicator $(Y(T)$ is the gross output of agriculture, in constant prices of 2010) (Table 3).

After performing the calculations using the method of least squares, the desired Cobb-Douglas production function takes the following form:

$$
Y=341 K^{0,08353} L^{1,70970} I^{0,32224} E^{-0,98789}
$$

The multiple correlation coefficient is $R=0.892$, the standard approximation error is 0.107 . Fisher's F-criterion calculated is 9.26 - this is greater than Fisher's F-criterion tabular (99\% confidence, reliability), which is 8.45 . This gives a $99 \%$ probability that the found Cobb-Douglas production function (8) corresponds to the initial data of the problem. Therefore, the constructed production function has satisfactory statistical characteristics (Table 4). The value of the multiple correlation coefficient indicates that the variation in the volume of gross output by $89.2 \%$ depends on the fluctuations of the factors included in the equation and depends by $10.8 \%$ on the factors that are not taken into account. Coefficient of determination $R^{2}$ has a satisfactory value $(0.796)$, the variance of the output $Y(T)$ is due to the regression of the selected levers of influence $(K, L, I, E)$ by $79.6 \%$.

Based on the actual values of gross output and their calculated values, a graphical model of the results of the Cobb-Douglas production function approximation is obtained (Figure 2). In addition to the multiple correlation coefficient, the high degree of accuracy of the regression equation is evidenced by a slight deviation of the calculated values from the actual ones.

Thus, in equation (8) the elasticity coefficients $a_{2}=1.70970$ and a $4=-0.98789$ reflect the influence of factors on performance. Because of $a_{2}$ far exceeds 1 , the main role in the growth of agricultural production is played by the number of the employed persons. In the case of an increase in the number of employees in agriculture by $1 \%$, an increase in gross output of agriculture by $1.70970 \%$ should be expected. The elasticity coefficient $a_{4}$ is negative; therefore, the quantity and quality of labour are influenced by environmental factors, namelypollutant emissions deteriorate the quality of life of the rural population and have a negative impact on crop yields. The sum $\left(a_{1}+a_{2}+a_{3}+a_{4}\right)=1,13>1$ shows the increasing effect of the economies of scale (value $f\left(x_{i}\right)$ increases more than value $x_{i}$ ), the growth of production outpaces the increase in cost factors, with the expansion

Table 3

Statistics for calculations of the production function $(Y(T)$ is the gross output)

\begin{tabular}{|c|c|c|c|c|c|c|c|c|c|c|}
\hline$T$, year & $\begin{array}{c}Y(T), \\
\text { mln UAH }\end{array}$ & $\begin{array}{c}K(T), \\
\text { mln UAH }\end{array}$ & $\begin{array}{c}L(T), \text { thous } \\
\text { persons }\end{array}$ & $I(T)$ & $\begin{array}{c}E(T), \\
\text { thous } \mathrm{t}\end{array}$ & $y_{1}=\ln Y$ & $x_{1}=\ln K$ & $x_{2}=\ln L$ & $x_{3}=\ln I$ & $x_{4}=\ln E$ \\
\hline 2008 & 101451 & 16682 & 3322.1 & 0.5399 & 7210.3 & 11.5 & 9.7 & 8.1 & -0.6 & 8.9 \\
\hline 2009 & 96274 & 9295 & 3152.2 & 0.5120 & 6442.9 & 11.5 & 9.1 & 8.1 & -0.7 & 8.8 \\
\hline 2010 & 90792 & 11311 & 3115.6 & 0.6479 & 6678.0 & 11.4 & 9.3 & 8.0 & -0.4 & 8.8 \\
\hline 2011 & 117111 & 17981 & 3410.3 & 0.5566 & 6877.3 & 11.7 & 9.8 & 8.1 & -0.6 & 8.8 \\
\hline 2012 & 110072 & 18564 & 3506.7 & 0.6072 & 6821.1 & 11.6 & 9.8 & 8.2 & -0.5 & 8.8 \\
\hline 2013 & 133683 & 18175 & 3389 & 0.5956 & 6719.8 & 11.8 & 9.8 & 8.1 & -0.5 & 8.8 \\
\hline 2014 & 139058 & 18388 & 3091.4 & 0.5793 & 5346.2 & 11.8 & 9.8 & 8.0 & -0.5 & 8.6 \\
\hline 2015 & 131919 & 29310 & 2870.6 & 0.5031 & 4521.3 & 11.8 & 10.3 & 8.0 & -0.7 & 8.4 \\
\hline 2016 & 145119 & 49660 & 2866.5 & 0.5093 & 4498.1 & 11.9 & 10.8 & 8.0 & -0.7 & 8.4 \\
\hline 2017 & 140535 & 63401 & 2860.7 & 0.4632 & 3879.1 & 11.9 & 11.1 & 8.0 & -0.8 & 8.3 \\
\hline 2018 & 158307 & 65059 & 2937.6 & 0.4363 & 3866.7 & 12.0 & 11.1 & 8.0 & -0.8 & 8.3 \\
\hline
\end{tabular}

Table 4

Regression analysis parameters for $Y(T)$ (gross output)

\begin{tabular}{|l|c|}
\hline Multiple correlation coefficient $\mathrm{R}$ & 0.892 \\
\hline Coefficient of determination $\mathrm{R}^{2}$ & 0.796 \\
\hline Standard approximation error & 0.107 \\
\hline Fisher's F-criterion calculated $\mathrm{F}_{\mathrm{p}}$ & 9.26 \\
\hline Fisher's F-criterion tabular $\mathrm{F}_{\mathrm{T}}$ & 8.45 \\
\hline Number of observations & 11 \\
\hline
\end{tabular}




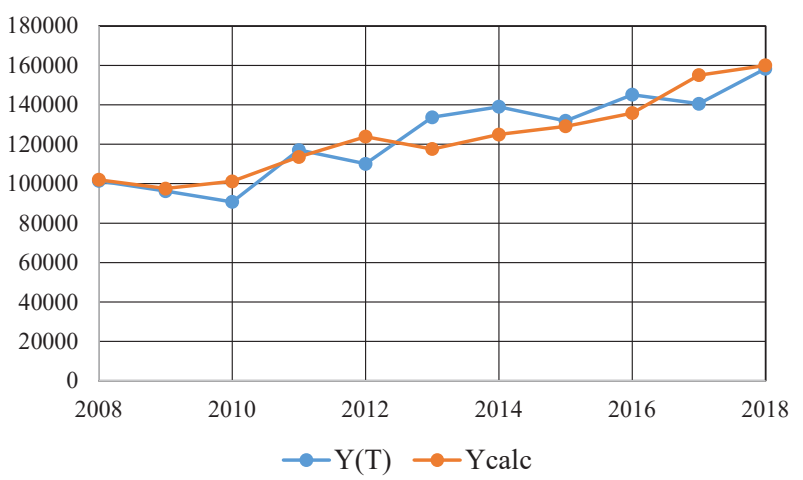

Figure 2. Results of the approximation of the Cobb-Douglas production function for gross output

of production, the average cost of resources per unit of output decreases.

The significant deviation of the elasticity coefficients (8) from 1 can be explained by the fact that other factors, such as political, social and administrative, can have an impact on the situational variable.

\subsection{The geometric interpretation of the model obtained}

The production functions obtained can be represented by the isoquant curve, which demonstrates different combinations of factors of production function (capital, labour, intellectual assets, environmental factor) in a particular state of technological development, i.e., it illustrates the elasticity of factor substitution, the intensity of various factors in the production process. The resulting output indicator $Y$ (gross output of agriculture) and the value of levers of economic growth $(K, L, I, E)$, for example, at the level of 2015, are recorded for the analysis of the production function $(8)$. The equation of the balance of fixed capital $(K)$ and labour $(L)$ at fixed values of other factors $(I, E)$ for the production function (8) has the following form:

$$
K=\left(\frac{Y}{a_{0}+L^{a_{2}}+I^{a_{3}}+E^{a_{4}}}\right)^{\frac{1}{a_{1}}}
$$

The isoquant that meets these conditions is shown in Figure 3. The curve indicates the substitution by capital $(K)$ within certain limits of labour $(L)$ and vice versa. The slope of the tangent to the isoquant (isocost), plotted at the point of the optimal ratio of capital and labour (Yankovyi, 2018, p. 374), gives evidence of the capital-intensive technical progress - the technological choice is shifted to capital as a more productive factor.

There is the equation of isoquant at fixed values of fixed capital $(\mathrm{K})$ and pollutant emissions $(E)$ :

$$
L=\left(\frac{Y}{a_{0}+K^{a_{1}}+I^{a_{3}}+E^{a_{4}}}\right)^{\frac{1}{a_{2}}}
$$

Figure 4 shows the curve of the balance of labour $(L)$ and the integral coefficient of intellectual assets $(I)$. The shape of the isoquant indicates a perfect substitution of

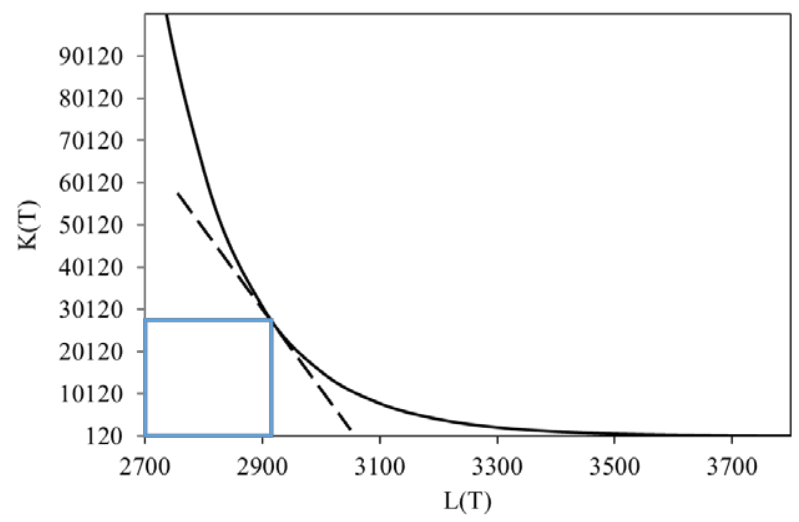

Figure 3. Balance of fixed capital $(K)$ and labour $(L)$ at fixed values of factors $(I, E)$

the production function $L$ and $I$ (insufficient amount of labour potential can be substituted by higher indicators of education, qualifications, abilities of workers), constructed tangent determines the qualitative indicators of labour potential $(I)$ a more productive factor in technical progress. The isoquant described by equation (9) is shown in Figure 5 also confirms the advantage of qualitative characteristics of human capital over material resources: insufficient amount of fixed capital can be partially offset by the growth of intellectual assets. The shapes of the isoquants in Figures 4 and 5 are close to linear isoquants. This demonstrates the perfect substitution of the factors of labour $(L)$ and capital $(K)$ with the factor $I$ and vice versa. This also confirms the importance of intellectual assets in production.

The equation of isoquant at fixed values of fixed capital $(K)$ and the integral coefficient of intellectual assets $(I)$ is described by formula (10). Figure 6 shows the curve of the balance of labour $(L)$ and pollutant emissions $(E)$, which reflects zero probability of substituting these two factors with each other. The shape of the balance curve of the capital $(K)$ and pollutant emissions $(E)$ built on equation (9) also confirms the impossibility of substitution (Figure 7).

Therefore, the isoquant variations shown in Figures 6 and 7 reflect the impossibility of combining

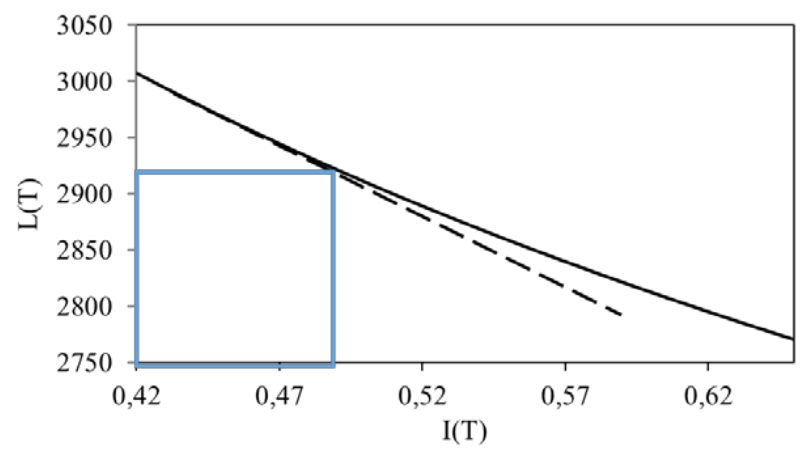

Figure 4. Balance of labour $(L)$ and the integral coefficient of intellectual assets $(I)$ at fixed values of factors $(K, E)$ 


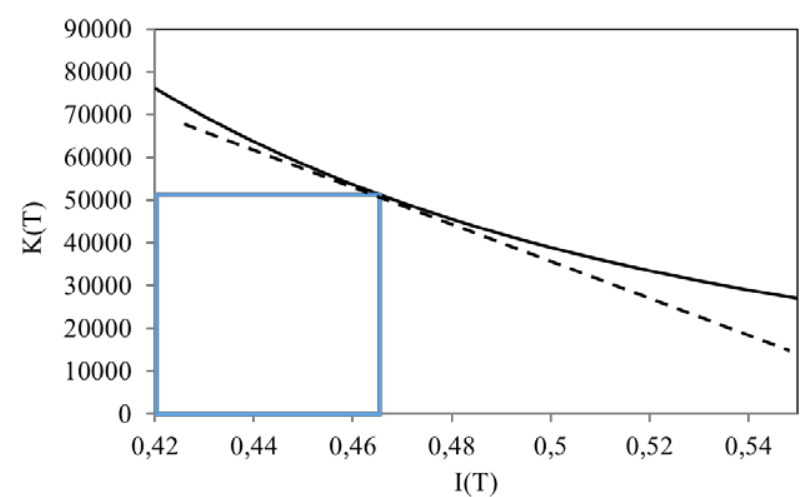

Figure 5. Balance of labour $(K)$ and the integral coefficient of intellectual assets $(I)$ at fixed values of factors $(L, E)$

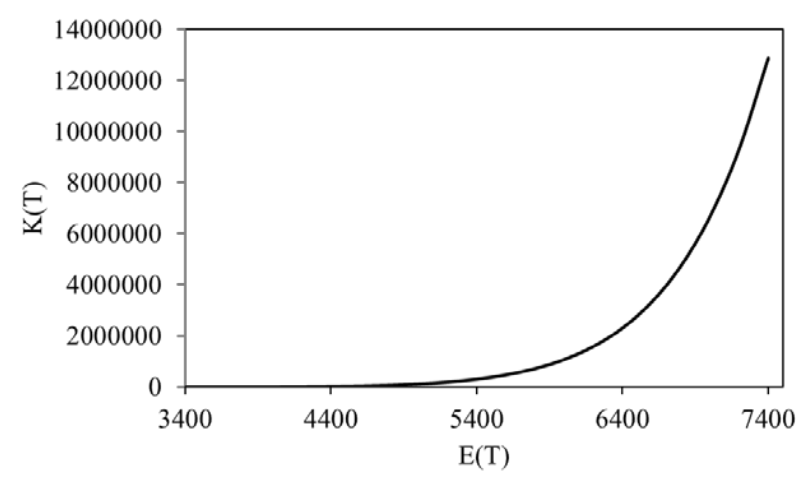

Figure 7. Balance of labour $(K)$ and pollutant emissions $(E)$ at fixed values of factors $(L, I)$

factors of production with the factor "pollutant emission $(E)$ ", we believe that the environmental factor makes a significant negative contribution and must be taken into account in the model of economic growth described by the production function.

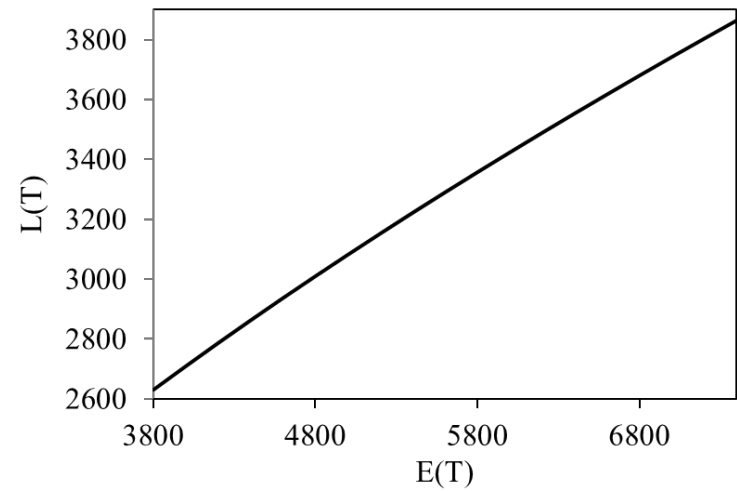

Figure 6. Balance of labour $(L)$ and pollutant emissions $(E)$ at fixed values of factors $(K, I)$

Since the four-factor Cobb-Douglas production function (8) is used for analysis, it is expedient to consider isoquants in the form of 3D surface (balance of three factors with one fixed factor) for a more detailed assessment of its adequacy.

Balance function of fixed assets $(K)$, labour $(L)$ and the integral coefficient of fixed assets (I) at a fixed value of pollutant emissions $(E)$ takes the form of the equation (9). The isoquant that meets these conditions is shown in Figure. The isoquant surface indicates the importance of the factors $L$ and $I$.

Equation of the balance of fixed capital $(K)$, pollutant emissions $(E)$ and the integral coefficient of intellectual assets $(I)$ at the fixed value of employees $(L)$ is described by formula (9), and is represented in Figure 9 as a surface. The shape of it shows a significant negative impact of increasing pollutant emissions $(E)$ and the positive effect of the growth of the integral coefficient of intellectual assets $(I)$.

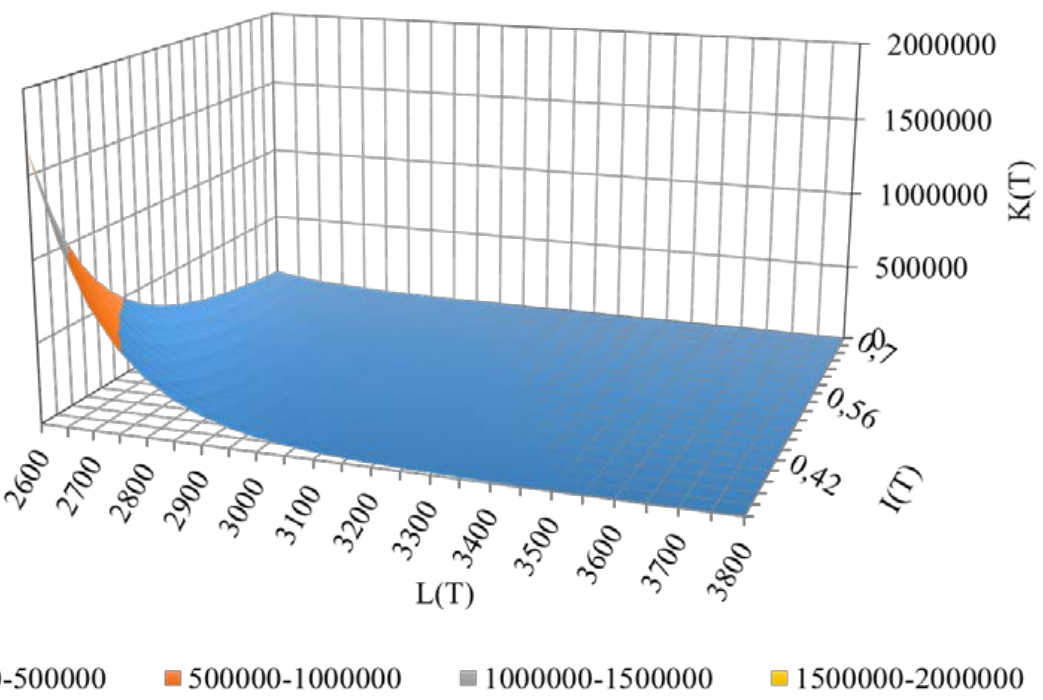

Figure 8. Balance of the fixed assets $(K)$, labour $(L)$ and the integral coefficient of intellectual assets $(I)$ at fixed values of pollutant emissions $(E)$ 


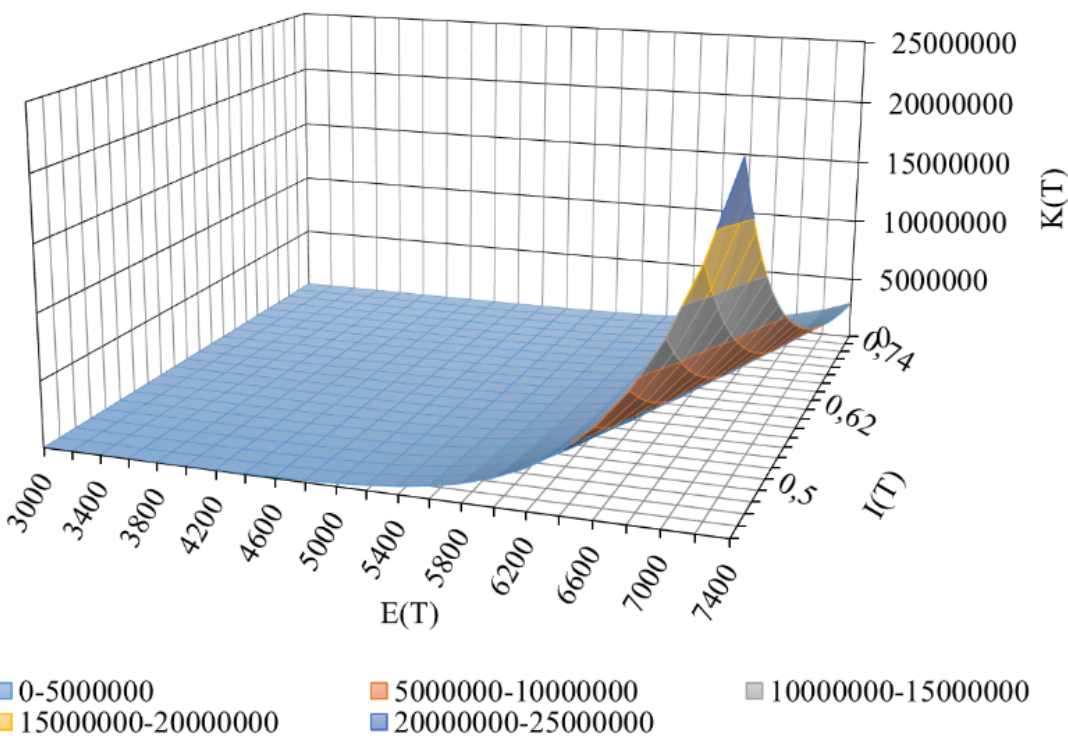

Figure 9. Balance of the fixed assets $(K)$, pollutant emissions $(E)$ and the integral coefficient of intellectual assets $(I)$ at a fixed value of the employees $(L)$

Figure 10 shows the surface of the balance of fixed capital $(K)$, labour $(L)$ and pollutant emissions $(E)$ at fixed values of the integral coefficient of intellectual assets (I) described by the equation (9).

Comparative analysis of the parameters of production functions for gross value added (7) and gross output (8) (Table 5) indicates a more efficient use of labour potential for processing agricultural raw materials and the creation of finished products, where technical progress $\left(a_{0}\right)$ and quality indicators of human capital $\left(a_{3}\right)$ have much more influence. Thus, the coefficients of elasticity are functions of factors that include the production function. This is shown in the studies of agricultural economics by Artyukh (2016) and Litvin (2017). We also agree with Shumska's (2007, p. 123) conclusions about the sensitivity of the coefficients of the production function to the political and institutional processes that take place in different periods of time. Ukraine is on the path to an efficiency driven economy that depends on key competitiveness factors: institutions, infrastructure, macroeconomic stability, health care and primary education (Vasylieva, 2018); these factors also affect the values of elasticity of coefficients.

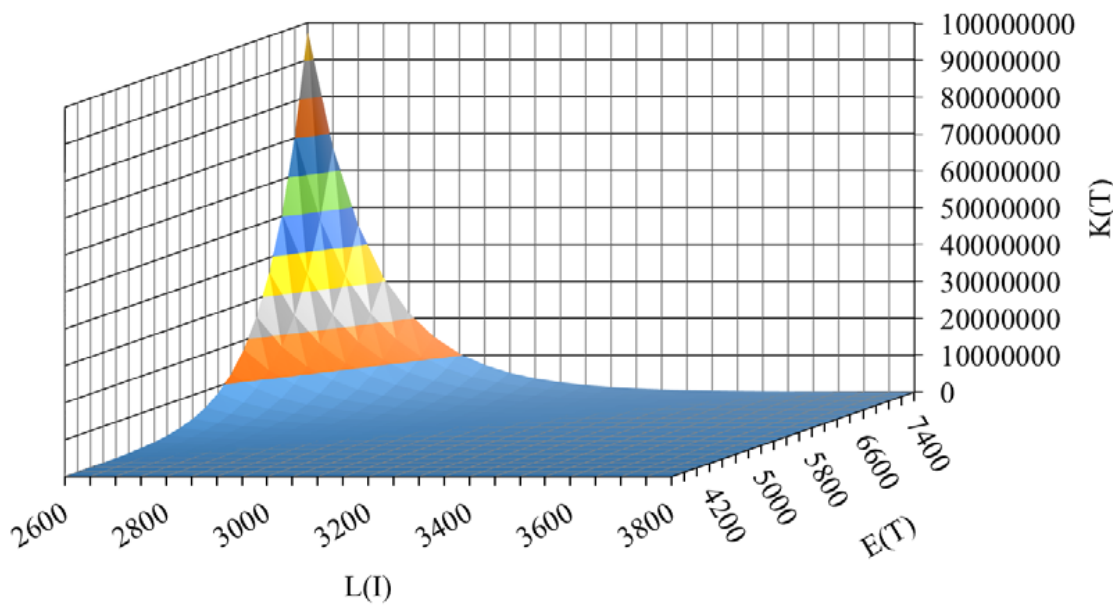

Figure 10. Balance of the fixed assets $(K)$, labout $(L)$ and pollutant emissions $(E)$ at a fixed value of the integral coefficient of intellectual assets $(I)$ 
Table 5

Results of modelling the production function

\begin{tabular}{|c|c|c|}
\hline parameters & $\begin{array}{c}Y(T) \text { gross value } \\
\text { added }\end{array}$ & $Y(T)$ gross output \\
\hline$a_{0}$ & 422388 & 341 \\
\hline$a_{1}$ & 0.34474 & 0.08353 \\
\hline$a_{2}$ & 2.63344 & 1.70970 \\
\hline$a_{3}$ & 1.60806 & 0.32224 \\
\hline$a_{4}$ & -2.86638 & -0.98789 \\
\hline$\left(a_{1}+a_{2}+a_{3}+a_{4}\right)$ & 1.72 & 1.13 \\
\hline
\end{tabular}

Using the Cobb-Douglas production function, econometric analysis with eco-socio-economic factors has shown that economic growth in agriculture is associated, firstly, with improved quantitative and qualitative characteristics of labour potential, and secondly, with growing capital investment and reducing pollutant emissions.

\section{Conclusion}

Economic growth of agricultural production in Ukraine (gross output) is labour-intensive, not capitalintensive, because $\left(a_{2}>a_{1}\right)$. This significantly depends on the quantitative indicators of the labour potential of rural areas $\left(a_{2}\right)$, which are gradually declining. This is due to negative demographic trends, which, in turn, has resulted in the degradation of rural areas, reduced employment and income.

The share of labour contribution to output is higher than the share of capital. This is justified by the presence of a significant private sector in agricultural production. Households mainly use manual labour, there are no opportunities to attract investment in technical and technological modernization of production; access to state support is limited due to low production volumes per farm. The prospects for economic growth of agricultural production are not to increase the number of resources, but to improve their quality. It is advisable to implement state support measures aimed at increasing the resource capacity of agricultural producers: subsidies for technical upgrades, investment loans for new capacity, reimbursement of capital expenditures for modernization of production, compensation for investment in land reclamation system, implementation of scientific and technical policy in the agricultural sector. To ensure sustainable growth of agricultural production, it is necessary to introduce innovative developments, resource-saving technologies, increase the use of intellectual capital (Potapov, 2020).

Efficient use of labour potential is the basis for economic growth in other sectors of the economy, reducing social tensions, ensuring food independence and security. Modelling how the resource factors act on output using the method of construction and calculation of parameters of the production function allows to predict the sustainable development of agricultural production under quantitative and qualitative changes in the use of labour and capital, as well as environmental factors.

In our opinion, the obtained results on the growing economies of scale give grounds to speak about the optimistic prediction of increasing the resource potential of agricultural production due to the growth of quantitative and qualitative indicators of labour potential, the prospects of which have been widened under decentralization and creation of new economic agents in rural areas.

It would be also beneficial to carry out research to factors of sustainable development of the agricultural sector using other econometric methods.

\section{References:}

Arrow, K., Chenery, H., Minhas, B., \& Solow, R. (1961). Capital-Labor Substitution and Economic Efficiency. The Review of Economics and Statistics, 43(3), 225-250.

Artyukh, M., \& Litvin, O. (2016). Zastosuvannia dyvidirialnoho ta multyhralnogo chyslen $\mathrm{v}$ doslidzhenni ekonomiky silskoho hospodarstva Ukrainy [Application of dividirial and multifaceted calculus in the study of agricultural economics of Ukraine]. Mathematical and computer modeling. Series: Technical Sciences, 13, 16-26. (in Ukrainian)

Asheim, B., Moodysson, J., \& Tödtling, F. (2011). Constructing regional advantage: towards state-of-the-art regional innovation system policies in Europe? European Planning Studies, 19(7). doi: 10.1080/09654313.2011. 573127

Barro, R., \& Sala-i-Martin, X. (1992). Convergence. Journal of Political Econom, 100, 223-251.

Çetin, M., Saygın, S., \& Demir, H. (2020). Tarım Sektörünün Çevre Kirliliği Üzerindeki Etkisi: Türkiye Ekonomisi İçin Bir Eşbütünleşme ve Nedensellik Analizi [The Impact of Agricultural Sector on Environmental Pollution: A Cointegration and Causality Analysis for Turkish Economy]. Journal of Tekirdag Agricultural Faculty, 17(3), 329-345. doi: 10.33462/jotaf.678764

Cobb, C. W., \& Douglas, P. H. (1928). A Theory of Production. American Economic Review, 18(1), 139-165.

Dedrick, J., Gurbaxani, V., \& Kraemer, K. L. (2003). Information technology and economic performance. ACM Computing Surveys, 35(1), 1-28. doi: 10.1145/641865.641866

Glinskiy, V., Serga, L., Alekseev, M., Samotoy, N., \& Simonova, E. (2018). The Development of the Food Industry as a Condition for Improving Russia's National Security. Procedia Manufacturing, 21, 838-845. doi: 10.1016/ j.promfg.2018.02.191 
Gosińska, E., \& Ulrichs, M. (2020). Sektorowe funkcje produkcji - wnioski z modeli panelowych dla Polski [Sectoral Production Functions: Results from Panel Models for Poland]. The Polish Journal of Economics, 302(2), 71-94. doi: $10.33119 / \mathrm{GN} / 116617$

Hopwood, B., Mellor, M., \& O’Brien, G. (2005). Sustainable development: mapping different approaches. Sustainable Development, 13, 38-52.

Karpenko, A. V. (2018). Rozvytok intelektualnykh aktyviv liudskoho potentsialu: teoriia ta praktyka [The Development of Intellectual Assets of Human Potential: theory and practice]. Zaporizhzhia: FOP V. V. Mokshanov. (in Ukrainian) Khvesyk, M. A., Bystryakov, I. K., \& Levkovska, L. V. (2012). Stalyi rozvytok: svitohliadna ideolohiia maibutnoho [Sustainable development: worldview ideology of the future]. Kyiv: Institute of Economics of Nature Management and Sustainable Development. (in Ukrainian)

Klewitz, J., \& Hansen, E. G. (2014). Sustainability-oriented innovation of SMEs: A systematic review. Journal of Cleaner Production, 65, 57-75. doi: 10.1016/j.jclepro.2013.07.017

Koptug, V. (1997). Itogi konferentcii OON po okruzhaiushchei srede i razvitiiu. Nauka spaset chelovechestvo [Outcomes of the UN Conference on Environment and Development. Science will save humanity]. Novosibirsk: Publishing house of the SB RAS SIC JIGGM. (in Russian)

Kramin, T. V., Grigoryev, R. A., Timiryasova, A. V., \& Vorontsova L. V. (2016). Vklad intellektualnogo i sotcialnogo kapitalov v ekonomicheskii rost regionov Rossiiskoi Federatcii [The contribution of the intellectual and social capital in economic growth of the Russian Federation regions]. Actual Problems of Economics and Law, 10(4), 66-76. doi: 10.21202/1993-047X.10.2016.4.66-76 (in Russian)

Kuzina, N. V. (2018). Funktciia Kobba-Dublasa i ee graficheskoe predstavlenie [Cobb-Douglas function and its graphical representation]. Kaluga Economic Bulletin, 2, 70-73. (in Russian)

Kuzmin, P., Kalashnikov, V., Kalashnykova, N., \& Watada, J. (2020). The Great Depression: Econometric Analysis and Fuzzy Regression. Journal of Advanced Computational Intelligence and Intelligent Informatics, 24(6), 785-791. doi: 10.20965 /jaciii.2020.p0785

Litvin, O., \& Artyukh, M. (2017). Uzahalnena vyrobnycha funktsiia, shcho yavno zalezhyt vid obiemnykh pokaznykiv resursiv ta kapitaloozbroienosti [The generalized production function, which depends explicitly on the volume indicators of resources and capital endowment). Bulletin of the National Technical University "KhPI". Series: Mathematical modeling in engineering and technology, 6, 51-56. (in Ukrainian)

Lukas, R. (1988). On the mechanism of economics development. Journal of Monetary Economics, 22, 3-42.

Lyashenko, I. M., \& Khrushch, L. Z. (2012). Optymalna prohrama pidpryIemstva ta ekoloho-ekonomichna vyrobnycha funktsiIa [The optimal program of the enterprise and ecological and economic production function]. Economic Bulletin of Donbass, 1, 184-188. (in Ukrainian)

Lyashenko, O. (2013). Model ekonomichnoho zrostannIa Solou-Svena z ekzohennym kapitalointensyvnym tekhnolohichnym prohresom [The model of economical growth of Solow-Swan with exogenous capital-intensive technological progress]. Investments: practice that experience, 15, 14-16. (in Ukrainian)

Mankiw, G., Romer, D., \& Weil, D. (1992). Contribution to the Empirics of Economic growth. Quarterly Journal of economics, 107(2), 407-437.

Marynych, T. (2017). Empirical assessment of long-term aspects of sustainable regional development. Economic Annals-XXI, 166(7-8), 86-90. doi: 10.21003/ea.V166-17

Meadows, D. H., Meadows, D. L., Randers, J., \& Behrens, V. W. (1991). Predely rosta [Limits of growth]. Moscow: Publishing house of Moscow State University. (in Russian)

Meadows, D., Randers, J., \& Meadows, D. (2018). Mezhi zrostannIa. 30 rokiv potomu [Limits of growth. 30 years later]. Kyiv: Pabulum. (in Ukrainian)

Moreno-Hurtado, C. A., Ochoa-Jiménez, D. A. \& Izquierdo-Montoya, G. L. (2018). A simplified endogenous economic growth model with social capital: Evidence for Ecuador. Business and Economic Horizons, 14(2), 168-184. doi: 10.15208/beh.2018.14

Novakova, L. (2020). The impact of technology development on the future of the labour market in the Slovak Republic. Technology in Society, 62, 101256. doi: 10.1016/j.techsoc.2020.101256

Odintsov, O., Yevtukhova, T., Vasylkonova, E., \& Kunchenko-Kharchenko, V. (2020). Influence of tax burden on economic development of agricultural enterprises in Ukraine. Journal of Eastern European and Central Asian Research, 7(1), 150-162. doi: 10.15549/jeecar.v7i1.328

Official site of the State Statistics Service of Ukraine (2020). Retrieved September 28, 2020, from http://www.ukrstat.gov.ua

Oliner, D., \& Sichel, D. (2000). The Resurgence of growth in the Late 1990s: Is Information technology the Story? The Jornal of Economic Perspectives, 14, 3-22.

Potapov, A. P. (2020). Modeling the impact of resource factors on agricultural output. Economic and Social Changes: Facts, Trends, Forecast, 13(4), 154-168. doi: 10.15838/esc.2020.4.70.9

Proclamation of Teheran (1968) Final Act of the International Conference on Human Rights, Teheran, 22 April to 13 May 1968. U.N. Doc. A/CONF. 32/41 at 3 via University of Minnesota Human Rights Library.

Pshenichnikova, S. N., \& Romanyuk, I. D. (2017). Analiz proizvodstvennoi funktcii Kobba-Duglasa dlia ekonomik Rossii i riada stran regiona Tcentralnoi i Vostochnoi Evropy [Analysis of the Cobb-Douglas production function 
for the economies of Russia and a number of countries in the Central and Eastern European region]. Proceedings of Southwestern State University. Economics series. Sociology. Management, V. 7, 3(24), 148-166. (in Russian)

Romer, P. (1986). Increasing returns and long-run growth. Journal of Political Economy, 94, 1002-1037.

Romer, P. (1996). Why, Indeed, in America? Theory, History, and Origins of Modern Economic Growth. American Economic Review, 86(2), 202-206.

Schumpeter, J. A. (1934). Theory of Economic Development: An Inquiry into Profits, Capital, Credit, Interest, and the Business Cycle. Cambridge, MA: Harvard University Press.

Shumska, S. S. (2007). Instrument vyrobnychoi funktsii v doslidzhenni ukrainskoi ekonomiky [The tool of the production function in the study of the Ukrainian economy]. Economics and forecasting, 4, 104-123. (in Ukrainian) Slavgorodska, Yu. V. (2016). Stalyi rozvytok v konteksti funktsionuvannia ahropromyslovoho kompleksu Ukrainy [Sustainable development in the context of the functioning of the agro-industrial complex of Ukraine]. Taurian Scientific Bulletin. Agricultural sciences, 96, 255-262. (in Ukrainian)

Solow, R. (1956). A Contribution to the Theory of Economic Growth. Quarterly Journal of Economics, 70(1), 65-94. Solow, R. (1957). Technical Change and the Aggregate Production Function. The Review of Economics and Statistics, 39(3), 312-320.

Solow, R. (1961). Capital Labor Substitution and Economic Efficiency. Review of Economics and Statistics. Retrieved October 12, 2020, from https://msuweb.montclair.edu/ lebelp/ACMSCapLabSubREAS1961.pdf

Suvorov, N. V., Akhunov, R. R., Gubarev, R. V., Dzyuba, E. I., \& Faizullin, F. S. (2020). Primenenie proizvodstvennoi funktcii Koba-Duglasa dlia analiza promyshlennogo kompleksa regiona [Application of the Cobb-Douglas production function for the analysis of the industrial complex of the region]. Economy of the region, 16(1), 187-200. (in Russian)

The future we want (2012). Resolution adopted by the General Assembly on 27 July 2012 (A/RES/66/288). Retrieved November 23, 2020, from http://srsg.violenceagainstchildren.org/sites/default/files/documents/ docs/A_RES_66_288_EN.pdf

Tkach, I. I. (2015). The core function of sustainable development. Actual problems of economy, 1(163), 59-66.

Tödtling, F., \& Grillitsch, M. (2015). Does combinatorial knowledge lead to a better innovation performance of firms? European Planning Studies, 23(9). doi: 10.1080/09654313.2015.1056773

United Nations Conference on Sustainable Development “Rio +20” (2012). United Nations. Retrieved October 18, 2020, from http://www.uncsd2012.org/

Vasylieva, O. (2017). Factors of Labor Productivity Growth in Agriculture of the Agrarian Region. Baltic Journal of Economic Studies, 3(4), 1-6. doi: 10.30525/2256-0742/2017-3-4-1-6

Vasylieva, O. (2019). The economic potential of sustainable development of the agricultural sector of Ukraine. European Journal of Economics and Management, 5(3), 14-21.

Vasylieva, T., Lyeonov, S., Lyulyov, O., \& Kyrychenko, K. (2018). Macroeconomic stability and its impact on the economic growth of the country. Montenegrin Journal of Economics, 14(1), 159-170. doi: 10.14254/18005845/2018.14-1.12

Yang, W., \& Zhao, J. (2020). Study on China's economic development from the perspective of strong sustainability. The Singapore Economic Review, 65(01), 161-192. doi: 10.1142/S021759081746002X

Yankovyi, O., Sotnychenko, L., \& Petrashevska, A. (2018). Determination of optimum of capital-labour ratio within two-factor production functions with non-zero substitution by the principle of equal margin. Baltic Journal of Economic Studies, 4(3), 372-378. doi: 10.30525/2256-0742/2018-4-3-372-378

Yankovyi, V. O. (2015). Vyrobnycha funktsiia z postiinoiu elastychnistiu zamishchennia resursiv [Production function with constant elasticity of substitution resources]. Socio-economic research bulletin, 3(58), $228-234$. (in Ukrainian)

Zygmunt, A. (2019). External linkages and intellectual assets as indicators of firms' innovation activities: results from the Czech Republic and Poland. Oeconomia Copernicana, 10(2), 291-308. doi: 10.24136/oc.2019.015

Zygmunt, A. (2020). Do Human Resources and the Research System Affect Firms' Innovation Activities? Results from Poland and the Czech Republic. Sustainability, 12(6), 2519. doi: 10.3390/su12062519 